\title{
Tension in a Value Co-Creation Context: A Network Case Study
}

\begin{abstract}
This study addresses tension and its consequent hurdles to the collaborative nature of value co-creation. Substantial research has focused on the benefits of value co-creation but much less so on its dark side. While some tension is inevitable, escalated tension can harm anticipated value and business relationships. The overlaps and disparities of formal and informal communication networks of two large construction projects are examined along with the tensions arising. To increase the breadth and depth of the empirical investigation, the presented network case study draws on survey data analyzed with Social Network Analysis as well as 45 in-depth managerial interviews. Structural, emotional and behavioural tensions are identified. The study suggests that tension triggered by one or a few actors can destabilize the network by creating unsustainable communication structures. Social Balance Theory is applied to study how unsustainable communication structures seek balance at a network level. We identify network patterns that can signal the presence of tension and structural imbalance in value cocreation, categorize several types of tension, and provide managerial implications.
\end{abstract}

Key words: Value Co-Creation; Tension; Communication Networks; Project Networks; Social Network Analysis, Network Case Study. 


\section{Tension in a Value Co-Creation Context: A Network Case Study}

\section{Introduction}

This study explores the paradoxical nature of tension in a collaborative value co-creation context. It focuses on the network imbalance caused by tension and its potential performancerelated and relational consequences. Value co-creation is defined as the joint activities of actors who exercise not only their individual agency, but also coordinate their actions to improve mutual value creation (Grönroos, 2012; Lusch \& Vargo, 2014). Drawing on various tension definitions (Bengtsson et al., 2016; Flint et al., 2002; Tidström, 2014), we conceptualize tension as the discomfort generated by ambiguity that can have various sources, such as contradictory and unclear communications, lack of communication, lack of sufficient planning, and incongruity between actors' aims. The problem with tension is that rising discomfort and pressure can disrupt or negatively influence the dialog concerning knowledge sharing and resource integration between network actors (Abosag et al., 2016) in the value co-creation process (Mele, 2011). We focus on three key aspects of tension (structural, emotional and behavioural) that have been explored in the strategic alliances and business-to-business marketing literatures (Pressey \& Vanharanta, 2016; Das \& Teng, 2000).

This study aims to contribute to the embryonic research stream examining the so-called 'dark side' of value co-creation by identifying the tensions that may arise in complex industrial networks (Chowdhury et al., 2016). While studies have attempted to address the negative aspects of value co-creation, these contributions are overwhelmingly from a business-toconsumer perspective (see, for example, Heidenreich et al., 2015; Edvardsson et al., 2011), and consequently neglect the tensions that may impede value delivery in industrial networks. 
A common misconception is that a key individual's influence diminishes as organisations grow. There can be acts, events, and flows of information (or the lack thereof) however, that are triggered by one (or more) 'very difficult' individuals that result in irrevocable tension at a group or network level (Woodside \& Baxter, 2013). In the presence of such tension unsustainable communication structures can evolve. This increases the risk of delivery failure, and subsequent financial and relational costs. Anchored in the Social Balance Theory perspective (Heider, 1946; Hummon \& Doreian, 2003), our research theorizes tension in an inter-organizational context. Social Balance Theory enables us to scrutinize the balance mechanisms in the network through interactions embedded in the cognitions of actors and within the network structure.

In this study, tension is examined at individual, group and inter-organisational levels, and is illustrated by two large-scale construction projects - one of which has been successfully delivered and the other remained dysfunctional. We employ a network case study methodology that combines semi-structured in-depth interviews with managers involved in both construction projects as well as survey data that reports on their formal and informal communication networks. Social Network Analysis (Borgatti \& Everett, 1992) is employed to analyse the communication structures and actors' network roles because of its capacity to examine relationships between actors that goes beyond a focus on the attributes of actors seen in more traditional social and behavioural research (Wasserman \& Faust, 1994).

Following this introduction, the study is structured as follows. Initially, we review the literature related to tensions and network tensions and outline a typology of tensions that provides the basis for the empirical study. Next, we introduce the procedures adopted in our network case study methodology. This is followed by the presentation of our results and the 
discussion. We conclude the study with implications for theory and practice as well as limitations and potential future research directions.

\section{Network Tensions and Value Co-creation}

Some tension is inevitable in business networks, especially when there are interdependencies between actors (Cadotte \& Stern, 1979). Some types of tension, such as creative tension (Autio, 2005), can have positive implications. Indeed, creative tension is the lifeblood of innovative progress, and fosters the discovery of the alternative ways of achieving improved outcomes. If managed appropriately, tension can act as a trigger for learning (Clarke, 1991; Elkjaer, 2004). Other types of tension can have a variety of potentially positive and negative outcomes, vis-a-vis tension in relation to consumer decision-making (Woodside \& Chebat, 2001), or tension in financial markets between dealers (Viswanathan \& Wang, 2004).

Tension has been claimed to be a characteristic feature of interaction between actors in value co-creation, especially in innovative contexts such as new product development (Campbell \& Cooper, 1999), hybrid organisations (Mitronen \& Möller, 2003), and organisational transitions (Spekman \& Carraway, 2006). This raises issues regarding the network context, dynamics, and performance aspects relevant to the tension phenomenon in a business-to-business context, which we now explore.

\subsection{Types of tension in value networks}

In a study examining 'dark' business-to-business networks (i.e. illegal price-fixing cartels), Pressey and Vanharanta (2016) identified three distinct types of network tension drawing on the strategic alliances literature (cf. Das \& Teng, 2000): structural, psychological and behavioural tensions. Structural tensions relate to issues of network governance and the way 
in which horizontal and vertical relationships collude and are intertwined with control mechanisms and managerial practices. Understanding how the horizontal and vertical relational perspectives are related has been a challenge in business research (Pryke, 2012).

Alternatively, psychological and emotional tensions may be caused by mistrust as well as the way in which actors are viewed by other actors in the network and their attitudes towards one another. Finally, behavioural tensions relate to the way actors operate within the network and its working practices, as well as the communication practices of actors. Behavioural tensions are characterised by actual actions, whereas other types of tension can remain passive.

While network tensions can have positive outcomes as noted, they may also create structural, psychological/emotional, or behavioural differences that inhibit cooperation and network value co-creation unless actors can overcome their differences for the sake of the network.

\subsection{Managing multiple network layers of tension}

Tension is pervasive across different layers of the network. Tension can have an individual actor focus; for example, managerial role conflict and issues with role clarity (Cummings et al., 1984) and expected behaviours. Network paradoxes often derive from incongruence between individual characteristics and organisational control systems or the tension between individual action and collective interaction (Håkansson \& Ford, 2002). For example, Watkins and Hill (2009) reveal dynamic tensions in buyer-seller relationships between individual egoism that seeks to extract the most out of exchanges and cooperative altruism that seeks benefits for the collective. 
Network interactions are often conceptualised as embedded (or layered); where the interactions between individuals are embedded within a wider network of institutions and relationships (Granovetter, 1985). This may lead to both consensus and conflict between the aims of various layers in the network. A specific example of conflicting aims is the tension between the 'theoretically desirable' and 'managerially possible' in the strategy building process (Verhallen et al., 1998). This sort of tension culminates at a senior/top managerial level. It can, however, easily diffuse into different 'network layers' of the organisation, for example, to relations between actors involved in managing routine distribution activities and those responsible for emergent networked product innovation activities (Weerawardena \& Mavondo, 2011); or tension between departments (e.g. marketing and engineering: Weinrauch \& Anderson, 1982).

In an inter-organizational setting tensions may arise because of the hurdles of alignment of actors' aims and ways of interaction (Johnston \& Pongatichat, 2008), and due to attempts of sustainable business relationship alignment (Cox, 2004). Tension may arise when one actor perceives that their goal attainment is being impeded by other actors (Gaski, 1984). It can destabilise relationship development (Fang et al., 2011) as it impels actors to withdraw from the interaction, while at the same time facilitating dejection and related emotions such as frustration and disappointment (Andersen \& Kumar, 2006), as well as feelings of stagnation (Gilliland, 2004). It can also create damage to relational intimacy that is difficult to repair (Wuyts \& Geyskens, 2005), and cause inter-organisational distrust (Johnsen \& Lacoste, 2016). In situations where buyers and sellers simultaneously compete and collaborate with each other (i.e. in coopetition), inherent contradictory and opposing forces may easily engender tension (Fernandez et al., 2014; Bengtsson \& Kock, 2014). 
Between firms, tension often arises around managing contractual arrangements (Rese \& Roemer, 2004), the heterogeneity of customer requirements versus supplier resources (Harrison \& Kjellberg, 2010), dissimilarities in technology adoption (Slater, 1993), and orientations (Merrilees et al., 2011). Tension in relation to the international marketing of industrial products is often rooted in changing, uncertain environments (Skarmeas et al., 2008; Koza \& Lewin, 1999). Thus, the literature highlights the presence of tension as potentially evident at all layers of business networks: tension can be person-specific, can arise between different employees (Möller \& Svahn, 2004), between the individual employee and the group, between buyer and seller and other inter-organisational collaborations. It can characterise the relationship atmosphere itself (Abrahamsen et al., 2012), and it can also be an inherent part of value co-creation in project networks (Mele, 2011).

At a functional level, if properly managed, constructive tension can have positive effect on performance. It would be, however, myopic to consider tension only when it is explicit and manifest, as tension can also indicate latent conflicts. It can derive from the competition for scarce resources, for example, when actors of project teams compete for unanticipated capacities interfering with other on-going projects (Vaaland \& Håkansson, 2003), or for increasing power asymmetry (Sutton-Brady et al., 2015).

Managing tension is certainly a challenge for many organizations. When extending group boundaries, trust can help manage the tension resulting from structural changes (Andersen \& Kumar, 2006). Interestingly, mutual trust building appears to be effective only if tension has not yet escalated to the level of imbalance (empirically demonstrated by Fang et al., 2011). The authors suggest that trust building contributes towards a balanced state of tension and facilitates the shift from short-term opportunism to the pursuit of long-term benefits. 


\subsection{Addressing network imbalance using Social Balance Theory}

Imbalanced changes in the network and tension are intertwined. Håkansson and Ingemansson (2011) maintain that in relation to knowledge creation issues in the construction industry, insufficient change in interaction networks may create significant tension. Social Balance Theory (Heider, 1946; Hummon \& Doreian, 2003) offers a fine-tuned theoretical framing to study tension in a value network context because it addresses the issue of network imbalance and explains how all interaction is embedded in the cognition of network actors. Consequently, changes in the cognition of actors relating to interactions can result in tension at various levels of the network.

Social Balance Theory provides useful insights on the tendency towards a balanced state of relationships that has relevance for a business marketing context. Almost all relationships (including business relationships) have a sentiment component. Sentiment tends to be symmetrical, and if not, it usually becomes symmetrical over time (Newcomb, 1981). Heider (1958) makes the implicit assumption that relations can be treated either as primarily positive or negative, with a possibility of neutral attitudes. If actors perceive a set of cognitive elements as being a system, they will prefer to maintain a balanced state among these elements. Imbalance in the network increases discomfort, which influences attitudes and directs efforts towards regaining consistency and balance. For example, actors normally either like each other or dislike each other. Where mismatched sentiments exist, this often result in attitudinal change in one or the other party. Social Balance Theory is thus helpful in examining this dynamic nature of network [im]balance. There is a tendency to reach a balanced state at all levels by actively trying to eliminate tension: "If no balanced state exists, then forces towards this state will arise. ... if change is not possible, the state of imbalance will produce tension. Either the dynamic characters will change, or the unit reactions will be changed through action or 
through cognitive reorganization" (Heider, 1958, p. 107-109). Similarly, Davis (1977) asserts that tension triggers a clustering effect that helps reach a structural balance at a network level, where tension can cause conflict and result in conflict resolution. Sources of tension may vary: the sentiment component can go beyond liking and disliking and may occur in the form of identification and misidentification with people or teams (Fink et al., 2009, Butcher, 2013). Liking may be present but because of differences in values, practices or other aspects, identification might not occur.

Hence, tension can arise in inter-personal, intergroup, inter-organizational and intercultural contexts (Banner, 1995). Heider (1958) distinguishes sentiment and unit relationships when studying balance and unbalanced states; sentiment relations represent interpersonal relationships, while units are separate entities that "are perceived as belonging together" (p. 176). Units are, for example, families, organizations, or other subgroups within organizations. Notably, in Heider's Balance Theory, balance does not necessarily represent positive relationships between actors. Indeed, a balanced state can be produced from positive or negative connections, or configurations of the two.

The Social Balance Theory principle (i.e. that network system evolution seeks balance and is often signified by a low level of tension) is supported by the empirical results of Jones et al. (1998). They demonstrate that the presence of collective tension is often a sign of network change, especially in the context of professional services. Actors navigate these tensions by choosing partners whose expertise compliments and extends their own skills and assets. Also, the value network as a system seeks balance through relationship building and dissolution in the interaction process, which is often characterised by tension as a by-product of change. We 
therefore conceptualise project networks as specific value networks in which tension is created due to network imbalance.

The remainder of the study seeks to empirically examine the 'dark side' of value cocreation in a network setting and explores the role that tensions can play in impeding value creation in business-to-business project-based networks to redress this imbalance. The propositions of this study are as follows:

P1) ... that an individual actor (or a few individual actors) can trigger tensions at a business network level, and

P2) ... that the consequently created unsustainable communication structures seek new balance through changes in the network.

The first proposition highlights the potentially disruptive role of a single individual at a group or network level and is based on previous studies (particularly Woodside and Baxter, 2010 and Van Maanen, 1978) that refute the view that only the activities of large groups of actors can result in tension at a system-level. We propose that one person can be the source of tension that then evolves through the network. The second proposition relates to the balancing mechanism outlined in Social Balance Theory. In this context seeking balance does not necessarily mean positive valence of emotions - relationship dissolution can also lead to a new balanced state.

Combining Social Network Analysis and Social Balance Theory creates synergies. Social Balance Theory helps to explain the imbalance created in this interconnected system and 
provides the theoretical lenses to study tension. Social Network Analysis enables us to explore the interconnectedness of actors. Social Network Analysis is useful in exploring the structural features of a network and in the identification of potential sources of tension. It does this by examining the gaps between the formal and informal communication networks.

\section{Methodology: Network Case Studies}

Järvensivu and Törnroos (2010) conceptualize network case studies as a specific subcategory of case studies used in business research, and suggest a moderate form of constructionism to inform this method. They point out that moderate constructionism allows the researcher to look at value creation from a community-oriented perspective, and this supports our theoretical approach in relation to value co-creation. Applying Woodside and Wilson's (2003) definition, a network case study can be defined as an empirical inquiry that investigates network-related phenomena (such as network capabilities, corporate social capital, network position and identity), network evolution (dynamics), the structure of the network (cliques, core-periphery networks, reciprocity) or a combination of these aspects within its reallife context, especially when the boundaries between the studied phenomena and the network context are not clearly evident. Munksgaard and Medlin (2014) advocate network case studies as an appropriate tool to investigate self- and collective- interests in a network setting. The use of multiple methods is accepted and favoured to triangulate the collected information and gain a more in-depth understanding about the case. We follow moderate constructionism that embraces the existence of multiple community-formed perceived realities (Korsgaard, 1996) and rejects the positivistic argument that we may have unmediated perceptions of absolute truth (Milton, 1996). 
The sampling of the construction project networks was theoretical (Yin, 1994) based on the opportunities they provided to observe tensions. The cases were chosen for two main reasons. First, because of the scope and significance of the projects; second, both included levels of innovation that challenged existing practices and technologies requiring new and innovative solutions.

We explored the delivery of two large scale construction projects. Both projects were valued at over $£ 8$ million, and the suppliers are leading firms in the UK construction sector. The Successful Project involved the design and implementation of an energy efficient construction technology that has previously been used by this client (a training and education provider) in other buildings. The project that proved dysfunctional and failed to meet its objectives set out to build a combined heat and power plant that utilised a specific type of environmentally friendly energy production, new at that point in time to the UK. Details of the projects appear in Table 1.

\section{Table 1 \\ Projects Overview}

\begin{tabular}{|c|c|c|}
\hline Value & $\begin{array}{l}\text { Case } 1 \text { Successful Project } \\
£ 8.5 \text { million }\end{array}$ & $\begin{array}{l}\text { Case } 2 \text { Dysfunctional Project } \\
£ 8 \text { million }\end{array}$ \\
\hline Purpose & $\begin{array}{l}\text { Office accommodation and conference/training } \\
\text { facilities }\end{array}$ & Combined heat and power generation \\
\hline Supplier & $\begin{array}{l}\text { A leading construction, development and services } \\
\text { group in the UK. The group employs } 11400 \text { people } \\
\text { worldwide and has annual revenue of } £ 2.1 \mathrm{bn} \text {. }\end{array}$ & $\begin{array}{c}\text { A leading construction and regeneration group } \\
\text { in the UK. The group employs over } 8500 \text { people } \\
\text { and has annual revenue of over } £ 2.5 \text { bn. }\end{array}$ \\
\hline Customer & Training and Education Provider & $\begin{array}{l}\text { Large-scale site with district heating system to } \\
\text { approximately } 30 \text { buildings. }\end{array}$ \\
\hline $\begin{array}{l}\text { Level of } \\
\text { Risk }\end{array}$ & $\begin{array}{c}\text { Medium, new variant of energy efficient construction } \\
\text { technology previously used by this client in other } \\
\text { buildings. }\end{array}$ & $\begin{array}{l}\text { High, if successful this will be the first working } \\
\text { combined heat \& power plant utilising this form } \\
\text { of energy production technology in the UK. }\end{array}$ \\
\hline $\begin{array}{l}\text { Planning } \\
\text { time frame }\end{array}$ & $\begin{array}{l}9 \text { months in planning, this data was collected over the } \\
\text { 24-month construction period. }\end{array}$ & $\begin{array}{l}3 \text { years in planning, this data was collected over } \\
\text { the } 24-\text { month construction period. }\end{array}$ \\
\hline
\end{tabular}

The successful project was completed on time, within budget, and was fully functioning as intended as a training facility. The failed project was delayed, and never fully completed. It 
does now offer power generation but is fuelled by mains gas rather than the renewable energy source intended. Thus, the intended goal of the project (to supply low carbon renewable energy to the site) was not achieved.

In total, 45 in-depth interviews and two focus groups were conducted with participants over a period of twenty-four months, with most respondents being interviewed at both the start and the completion of the construction phase of the project. In addition, 14 design team progress meetings were attended. In each of these meetings, official progress documents were collected and field notes were made. Interviews normally took 60-90 minutes, and were digitally recorded, transcribed and coded using AtlasTI v6 software (Muhr, 2011), following the coding procedure outlined by Strauss and Corbin (1998). Internal validity was controlled through interviewing respondents at different points in time, and reliability was ensured using a case study protocol.

Social Network Analysis was employed for the structural analysis of actors and ties using the UCINET 6 software (Borgatti et al., 2002). In an extended interpretation of the method (Bellotti, 2016), however, the conducted in-depth interviews also fall under the umbrella of Social Network Analysis. For a better understanding of the methodological principles which underpin Social Network Analysis we suggest consulting, for example, Wasserman and Faust (1994) or Borgatti and Everett (2013). To ascertain communication behaviours, we drew upon the work of Mohr and Nevin (1990) who characterise frequency, direction (uni or bidirectional) and modality (more formal vs. more informal modes) as important aspects of communication. We therefore asked each respondent to complete a questionnaire in which they stated who they communicated with (i.e. their 'ego network'; Monge \& Contractor, 2003), on a three-point scale $(3=$ frequent/sustained, $2=$ moderate/some, or $1=$ infrequent/occasionally $)$, 
and how often they communicated with them. This was collected for both formal (meetings, memos, official documents and sign-offs) and informal communication modes (see Kotlarsky et al., 2014). As explained by Hartman and Johnson (1990), the communication structure of a collaboration is composed by both formal and informal communications and is not reducible to either.

Table 2

\section{Project Roles Overview}

\section{Client Team \\ (e.g. Client Financial Representative, Project \\ Director, Project \\ Administrator)}

\author{
Client Team \\ Representatives \\ (e.g. Project \\ Managers and their \\ Quantity Surveyors)
}

\author{
Design Team \\ (e.g. Architects, \\ Mechanical and \\ Electrical Engineer, \\ Structural \\ Engineers)
}

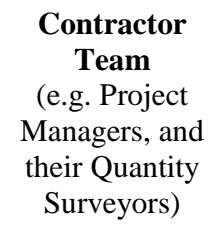
their Quantity Surveyors)

$\begin{array}{ccccc}\text { Successful Project* } & 3 & 3 & 4 & 3 \\ \text { Dysfunctional Project* }^{*} & 3 & 1 & 5 & 4\end{array}$

* There are specialists such as building controller, health and safety officer, clerk of works, landscape specialists and acoustic specialists who primarily do not belong to any of the four subgroups.

Informal communications in this study included, but were not restricted to, advice seeking (Brennecke \& Rank, 2016). All participant-driven and not formally organized communications (including corridor chats, site visits, and other forms of spontaneous communication such as discussions over coffee), fall under this umbrella.

\section{Data Analysis and Results}

In studying how tension evolved in the two projects, we examined the behavioural, psychological and structural tensions experienced by actors on each project and their impact on value co-creation. In the case of behavioural and psychological tensions, we focused on the interview data because it provides us with fine-grained information about the emotional and attitudinal complexity of the cases. 
To explore structural tensions Social Network Analysis was deployed. Sociograms help to identify 'tension links' in the network context of two projects, which was also informed by our qualitative understanding. Primarily, we have utilised two forms of structural indices because these were the most relevant in terms of comparing the two cases from a structural tension perspective. First, we have used Krackhardt's graph theoretical dimensions of hierarchy (Krackhardt's GTD), as this measure tells us something about the hierarchical structure of the network (Hanneman \& Riddle, 2005). In a pure hierarchical form, every node would have a directed connection and have an in-degree of 1 (one inward directed contact) except the first node from which the chain of connections starts (i.e. A to B to C to D). Secondly, we employ a Quadratic Assignment Procedure (QAP) correlation, which calculates the association between the relationships in two matrices (i.e. two networks) and uses quadratic assignment procedures to test the significance of the association (Wasserman \& Faust, 1994).

\subsection{Structural Tension}

An unbalanced network structure can lead to structure-related tension, which - as a vicious circle - can activate other types of tensions that may impede value co-creation. We limit our investigation of structure to one point of time when the survey was taken. The two projects ran parallel to each other and there were nine professionals who participated in both projects, as working on multiple projects is not rare in the construction industry. From a research perspective, however, their impact is very important. These are the actors who have experience in both informal and formal communications in the two projects running parallel to each other. Their different behaviours on the two projects can signal network-level issues, especially regarding tension. Table 3 shows some relevant network-level comparative statistics that provide an overview of the communication networks. 
Table 3 Relevant network-level indices

\begin{tabular}{|c|c|c|c|c|c|}
\hline & $\begin{array}{l}\text { Data } \\
\text { type }\end{array}$ & $\begin{array}{l}\text { Successful Project } \\
\text { Formal } \\
\text { Communications }\end{array}$ & $\begin{array}{l}\text { Successful Project } \\
\text { Informal } \\
\text { Communications }\end{array}$ & $\begin{array}{l}\text { Dysfunctional } \\
\text { Project Formal } \\
\text { Communications }\end{array}$ & $\begin{array}{l}\text { Dysfunctional } \\
\text { Project Informal } \\
\text { Communications }\end{array}$ \\
\hline $\begin{array}{l}\text { Value Density } \\
\text { (the ratio of all tie strength that is } \\
\text { actually present to the number of } \\
\text { possible ties) }\end{array}$ & Value & $\begin{array}{c}0.30 \\
(\operatorname{std} 0.71)\end{array}$ & $\begin{array}{c}0.30 \\
(\operatorname{std} 0.75)\end{array}$ & $\begin{array}{c}0.14 \\
\text { (std } 0.49)\end{array}$ & $\begin{array}{c}0.15 \\
(\text { std } 0.56)\end{array}$ \\
\hline $\begin{array}{l}\text { Degree Centrality } \\
\text { (dispersion of actors' degree centrality } \\
\text { compared to the max. attained value) } \\
\text { Out-Degree }\end{array}$ & Value & 0.08 & 0.07 & 0.10 & 0.11 \\
\hline In-Degree & Value & 0.10 & 0.09 & 0.06 & 0.04 \\
\hline $\begin{array}{l}\text { Clustering Coefficient } \\
\text { (Weighted Overall graph clustering } \\
\text { coefficient) }\end{array}$ & Binary & 0.42 & 0.40 & 0.39 & 0.34 \\
\hline $\begin{array}{l}\text { Transitivity } \\
\qquad(\% \text { of all triads that are transitive) }\end{array}$ & Directed & $2.37 \%$ & $2.05 \%$ & $.76 \%$ & $.57 \%$ \\
\hline $\begin{array}{r}\text { (\% of relations that could easily be } \\
\text { transitive and are so) }\end{array}$ & Directed & $56.22 \%$ & $51.19 \%$ & $49.01 \%$ & $43.94 \%$ \\
\hline $\begin{array}{l}\text { Geodesic Distance } \\
\text { (Average distance) }\end{array}$ & Value & 1.46 & 1.45 & 1.26 & 1.33 \\
\hline (hierarchical) & Directed & .63 & .54 & .68 & .74 \\
\hline
\end{tabular}

Value density (Wasserman \& Faust, 1994) is the ratio of all tie strength that is present to the number of possible ties. In other words, it describes the portion of the potential connections in the networks that are actual connections. However, lower density does not imply a less favourable network structure and what 'dense' means is relative considering the context. The density of the formal and informal communication networks of the Dysfunctional Project are approximately half of the density of the formal and informal communication networks. The clustering coefficient shows the degree to which actors in the network tend to cluster together. A related structural tendency, transitivity, which is also higher in the case of the Successful Project's communication networks, considers patterns of trios (more specifically, the proportion of closed triangles). The groups in the Successful Project appear to be slightly more tightly knit (higher density) compared to the Dysfunctional Project (lower density).

Degree centrality is a count of the number of edges incident upon a given node and it comprises of two measures: in-degree and out-degree centralities (Borgatti \& Everett, 2006). 
In-degree is a count of the number of ties directed to the nodes and out-degree is the number of ties that derive from the nodes. It is remarkable that whereas the in- and out-degree indices both in the formal and informal communication networks of the Successful Project $(0.1 / 0.08$ and $0.09 / 0.07)$ are close to each other, there appears to a gap between the in- and the outdegrees of the formal and informal networks of the Dysfunctional Project. The in-degree centrality measures of the formal as well as informal communication networks of the Dysfunctional Project are considerably lower than the out-degree measures that signals a higher level of one-way communication instead of interaction.

The geodesic distance shows the length of the shortest path between corresponding vertices in the graph. The 6-degrees of separation phenomenon - where a node is said to be connected to any other node by no more than six intermediate links (noted first by the Hungarian poet Frigyes Karinthy in 1929; and academically investigated by Watts, 2004) is an illustrative example for geodesic distance. In both communication networks, actors are fairly close to each other, though they are even closer in the Successful Project. Even though the explanatory power of these indices is limited, we can see that the density, clustering coefficient, geodesic distance and transitivity of both the formal as well as informal communication networks of the Dysfunctional Project are lower compared to those of the Successful Project.

Krackhardt GTD, especially hierarchical Krackhardt GTD appears to be more informative. The hierarchical Krackhardt GDT index in the case of the Dysfunctional Project's informal communications $(0.74)$ is higher than the formal and informal communications' $(0.63$ and 0.54$)$ and higher even than the Dysfunctional Project's formal communications' (0.68). This indicates that the informal communications of the Dysfunctional Project were the most 
hierarchical among the formal/informal communication networks for both projects. Krackhardt GDT is an indicator of tension between different facets of organisational power and authority (Astley and Sachdeva, 1984). If we apply this theory in the light of the Krackhardt GDT indices, it is possible that tension in the informal communications of the Dysfunctional Project was higher not only compared to the Successful Project's communication networks but even compared to the formal communications of the same project. Informal communications can decrease uncertainty and tension (Schweiger \& Denisi, 1991) - in cases where informal networks overlap less with formal networks, managing tension with the help of informal chats could most probably be more challenging.

The sociograms for both the formal and informal communication networks, together with the interviews, can reveal some structure related tensions. The sociograms of the communication networks are as follows:

Figure 1: Successful Project - Formal Communications

$$
\text { Insert Figure } 1 \text { about here }
$$

Figure 2: Successful Project - Informal Communications

$$
\text { Insert Figure } 2 \text { about here }
$$

Figure 3: Dysfunctional Project - Formal Communications

$$
\text { Insert Figure } 3 \text { about here }
$$

Figure 4: Dysfunctional Project - Informal Communications 
The findings reveal that the formal and informal networks in the case of the Successful Project are very similar. Even though the difference is not very striking between the formal and informal communication networks of the Dysfunctional Project, there are some characteristics that we would like to draw attention to. Looking at the informal communications of the Dysfunctional Project, the Energy Manager and the Project Manager are in brokerage positions in which they control communication flows. These managers are between important constituencies, and without them, several colleagues would be cut off from the flow of informal information as they are only connected to the network via these actors. We learned from the interviews that tension existed between these two managers.

Figure 5: Rotated network of the Dysfunctional Project - Informal Communications

Insert Figure 5 about here

The network rotation procedure (Figure 5) follows that of Pryke (2012), and reveals two tension-related issues. First, that there are multiple communication channels between the project members and the client. This leaves the team with a higher risk of miscommunication and increases the negotiation power of the client at a group level. Second, it also shows that responsibilities might not be well-defined. Our understanding from the interview data confirms that tension arose in and around communication with the client. This echoes the concerns of Jones et al. (1998) who emphasize the major trust-related risks of this type of structural tension. 
Figure 6: Tension network: the fit-out team and the design team

Insert Figure 6 about here

Figure 6 shows that after revisiting the interviews we can identify two teams that struggle with tension: the 'fit-out team' and the 'design team', which are not very well connected. The red link represents relationships with intense tension. The two teams are not very close to each other geographically, and that might contribute to the identified tension between the two groups.

On the one hand, the QAP correlation between the formal and informal communication networks of the Successful Project is very strong $(r=0.906)$ and significant $(p<0.05)$. On the other hand, the QAP correlation between the formal and informal communication networks of the Dysfunctional Project are somewhat weaker $(\mathrm{r}=0.716)$ and significant $(\mathrm{p}<0.05)$. While the lower $r$ in the case of the Dysfunctional Project is due to structural issues (i.e. the brokerage position of two team members in the informal communication network), it is still important to note that overall the overlaps between formal and informal communications were deemed to be stronger in the case of the Successful Project. Considering that effective informal communication enhances formal communications which support problem-solving (Simpson \& Dansereau, 2007), we can assume that less tension was created or remains unresolved in the Successful Project than in the Dysfunctional Project network.

As noted, there were nine people involved in both construction projects at the time when the survey was completed. Not surprisingly, the formal communications of the two projects are different $(\mathrm{r}=.796 ; \mathrm{p}<0.05)$, as the people in key managerial roles on each project were 
different. The informal communication networks, however, should be theoretically the same for the nine people who worked on both projects, and hence the correlation should be 1 . As Table 4 indicates, however, we can see that the correlation is $\mathrm{r}=0.952(\mathrm{p}<0.05)$. This suggests that the informal communications were different between the very same people depending on whether they were working on the Successful or the Dysfunctional Project. This surprising difference indicates that the same people behaved differently in communicating informally with each other depending on which of the projects they were communicating about.

Table 4: Correlation of Formal and Informal Communications by Project for Shared Members Only

\begin{tabular}{|c|c|c|c|c|}
\hline & $\begin{array}{c}\text { Successful Project } \\
\text { Formal } \\
\text { Communications }\end{array}$ & $\begin{array}{c}\text { Successful Project } \\
\text { Informal } \\
\text { Communications }\end{array}$ & $\begin{array}{c}\text { Dysfunctional Project } \\
\text { Formal } \\
\text { Communications }\end{array}$ & $\begin{array}{c}\text { Dysfunctional Project } \\
\text { Informal } \\
\text { Communications }\end{array}$ \\
\hline $\begin{array}{c}\text { Successful Project } \\
\text { Formal Communications }\end{array}$ & 1.000 & 0.868 & 0.796 & 0.829 \\
\hline $\begin{array}{c}\text { Successful Project } \\
\text { Informal } \\
\text { Communications }\end{array}$ & 0.868 & 1.000 & 0.896 & 0.947 \\
\hline $\begin{array}{c}\text { Dysfunctional Project } \\
\text { Formal Communications }\end{array}$ & 0.796 & 0.896 & 1.000 & $\mathbf{0 . 9 5 2}$ \\
\hline $\begin{array}{c}\text { Dysfunctional Project } \\
\text { Informal } \\
\text { Communications }\end{array}$ & 0.829 & $\mathbf{0 . 9 5 2}$ & 0.947 & 1.000 \\
\hline
\end{tabular}

All $\mathrm{p}<0.05$

Based on the foregoing, we can assert that structural network imbalances can result in tensions that inhibit value co-creation in complex networks. This may be due to some actors (or even professional teams) being isolated and cut off from the flow of informal information or else having a tenuous link via one key actor who may act as a valuable information broker within their network.

\subsection{Emotional Tension}


Turning next to emotional tensions that may impede value co-creation in business networks, we find initially that some professionals felt unheard and under-appreciated within their network. Even if these critical cases were described as technical matters, the underlying issue seems to be deeply emotional in nature. The Structural Engineer on the Dysfunctional Project explained it as follows: "All of these things add up to make what seems like a, something that's quite simple, and from the outside you could say, "Well, actually why did that take so long to do?" Well the answer is, "Because it's more complicated inside than what you would normally do." His expertise was often questioned and he felt rushed on a regular basis, even though he made several attempts to explain the time constraints he faced as well as other resources required to complete his task.

The feeling of being excluded was also seen to cause emotional tension: "Yes, our design team contractor and clients' team and contractor and that sort of thing and there's sometimes, I wouldn't say animosity, but there is this feeling that there is this distinct line between you" (Engineer 2, Dysfunctional Project). A specific type of emotional tension can be the inner urge to impress someone: "And of course in the background I think have this desire to impress [name] and [his company] so they could get more work" (Engineer 3, Dysfunctional Project).

Actors have various levels of willingness and/or ability to proactively interact with others around them. The impact of a single actor can influence others in a way that they wish to emotionally distance themselves and disengage in related communication flows. Situations like this can be very stressful both for the person and their environment: "I'm very concerned, and I know very well that they won't work the way I work. I totally fail to understand why and I continually over many years represent my own way of working but it isn't adopted. (...) There 
must be but I can't think of one where somebody's expecting me to work in totally new ways. I defend my known good paths ardently” (Fit-out manager, Dysfunctional Project).

As illustrated, psychological and emotional tensions can inhibit value co-creation in networks in diverse ways. For example, we found instances where professionals felt unappreciated and perceived that their expertise was being excluded from technical problem solving. Further, the extent to which actors could proactively engage with other network members and maintain communication flows, particularly between actors from different professional backgrounds, seemed valuable in avoiding network tensions, as did actors' coping mechanisms (such as the use of humour) to deal with highly pressurised working environments.

\subsection{Behavioural Tension}

For both projects, differences in ways of working among colleagues often manifest as a source of tension. This occurred even though several managers mentioned change and flexibility as a key element of their ordinary working practices. The senior project manager of the Successful Project highlighted: "People who have been in the trade, you know, a lot of years, do get set in their own ways. And trying to convince them that there are better ways to do it can sometimes be quite difficult." As the Architect of the Successful Project stated: "I like the old-fashioned way of doing things", yet it seemed to cause behavioural tension for both those who initiated a change in practices and for actors who intended to carry on with the old practices.

The senior project manager of the Successful Project went on to describe the tension involved in different communication behaviours, depending on the level of knowledge being communicated and to whom: “... obviously the specialist has got deeper knowledge than the 
non-specialist ... I think it does require the person to be able to 'peak and trough', so to speak ... and there's different languages that are needed, probably takes longer to explain in the trough that it does in the peak because there's not the understanding from the receiver in the communication process." Clearly a mismatch in knowledge backgrounds can lead to tensions in communication behaviours.

Behavioural tensions also derive from personal likes and dislikes. For example, who wanted to collaborate with whom, or who wanted to avoid joint work with a network member. "I can think of examples where personalities have got in the way of-say someone's ego is a little bit too inflated and got in the way of the project ... to put it politely ... that person needed to understand their role and the effect they were having on the rest of the team." However, the prospect of potential future projects pursued together hindered some professionals from freely expressing their opinions and concerns. As one of the Engineers at the Successful Project reported: “...you might think 'Right I want to take a hard line here.' But you think 'Well do I really want to upset this guy to get to the point where he says, 'I'm never going to work with him again.' And that works both ways because you might have a subcontract who says, 'I don't want to work with [him] again.' Because he feels he's been hard done by." This sort of behavioural tension potentially belongs to the dark side of long-term collaboration, especially if this behavioural tension causes issues for problem solving.

There were behavioural tensions due to geographical distance. The fact that some colleagues worked at separate locations, and had to travel or talk via the phone, did not really support smooth communications according to one of the members on the Dysfunctional Project (the structural engineer) who commented: “Because sometimes, it's very difficult on the phone to say, 'Well what about this area here or this area."' Interestingly, this view was not shared 
by his project manager on the Dysfunctional Project, who stated that: "When I feel there is a lack of progress, I intervene and try and find out what the problems are, I would simply write them down [in an email] .... So, by iterations, results are finally achieved. Now that is how I do it, but the other team prefer to hold a meeting face-to-face, which I don't find useful." A lack of formalised and fact-to-face communications was a particularly noticeable feature of the Dysfunctional Project, and created strong tensions on the project. This highlighted how some means of communications can adversely influence problem-solving and may cause behavioural tensions. Finally, there were also behavioural tensions due to time constraints.

Factors causing behavioural tensions that may impede value co-creation in networks spanned a number of areas including: differences in working practices (particularly tensions felt by encouraging some actors to adopt current best practices); divergent communication practices (often based on actors' knowledge and professional backgrounds); the geographical distance between some network members based in different locations; the likes and dislikes between network members; and time constraints were all seen to be factors that might restrict value co-creation.

\section{Discussion}

In this study, we advance research on tension and value co-creation by examining it through the lens of Social Balance Theory. Managing tension in an inter-organizational context is a significant challenge. Foremost among the issues is dealing with the ubiquitous and equivocal nature of tension. Current academic knowledge on preconscious cognitive processing by managers and how they act to resolve tension and imbalanced states in a network context is lacking. 
First, this study demonstrates how elements of Social Balance Theory can illuminate the understanding of tension in business relationships. Previously, Social Balance Theory has been applied to the examination of job-related stress (Smith \& Sainfort, 1989), group problem solving (Adejumo et al., 2008), consumer behaviours (Woodside \& Chebat, 2001; Woodside, 2004), firm-consumer relations (Carson et al., 1997), and triadic firm relationships (Phillips et al., 1998). Applying Social Balance Theory, Hummon and Doreian (2003) assume that tension can be created when an imbalance between actors is present, with respect to the distribution of affective social choices, and that this can lead to the structural rearrangements of relationships.

Secondly, we present network patterns to detect the potential presence of tension by comparing informal and formal communications, as well as studying the structure of these networks using Social Network Analysis. We show discrepancies between informal communication networks between the same actors in relation to different projects can signal the presence of tension (QAP correlation). Also, the study of the rotated informal communications network of the Dysfunctional Project (Figure 5) enhanced by the qualitative data suggests that the presence of multiple parallel communication channels with the client, especially if not well-coordinated, can become a source of tension. While this result is not necessarily surprising, it supports the claim that the strained co-existence of channels is not rare in the construction industry and that these channels are often a mix of official and ad hoc channels (Shibeika \& Harty, 2015).

Finally, we demonstrate how the impact of one key individual in creating tension can encourage the development of unsustainable structures in the network of actors. The data analysis supports the propositions about the ability of individual actors to create network-level 
tension. This is in line with Woodside and Baxter (2013), who explain that the presence of a difficult individual involved in the business-to-business decision making process can put the anticipated positive outcome at risk. This is aligned with the findings of Makkonen and Olkkonen (2017), who emphasize the role of the actors' habitus in value co-creation and value co-destruction.

\section{Conclusions}

One of the central arguments of this study is that networks seek balance when unsustainable structures evolve. Therefore, we studied project networks as specific value networks in which tension is created when network imbalance is present. We studied tension in two large-scale construction projects, based on a triumvirate of tensions (psychological/emotional, behavioural and structural tensions). An example of behavioural tension in our study is the conflict between new and old practices. Emotional tension derived, for example, from actor's perceptions of not being listened to or appreciated - while some managers even felt they had been ignored. In identifying structural aspects of tension using Social Network Analysis, we found the Krackhardt GDT index of hierarchy particularly useful.

Interestingly, the informal network of the Dysfunctional Project proved to be the most hierarchical, which can be an indicator of tension. There is a direct relationship between Krackhardt's work on hierarchy and Social Balance Theory (Doreian \& Krackhard, 2001). Doreian and Krackhard examine the transitivity principle in relation to Social Balance Theory, positing that over time balanced triads become more frequent while imbalanced triads become less frequent (i.e. there is a movement towards a balanced state). The brokerage position of a specific key actor in the informal network of the Dysfunctional Project was a sign of potential 
tension due to the more problematic collaboration between actors who are connected to the network through the broker alone (Lingo \& O’Mahony, 2010). The qualitative data helped to illuminate these underlying sources of tension in the network at the level of individual actors. The role of one key individual appeared to be crucial in the culmination of tension.

The foregoing findings highlight the potential 'dark side' of value co-creation, and the compendium of factors (and tensions) that may inhibit the delivery of value in complex industrial networks. While previous studies have largely overlooked the factors that may impede value co-creation in business networks, the present study illustrates that tensions between actors may influence network problem solving, the timely flow of information between actors, the ability for actors to cope in pressurised work environments, and the ability to create effective working practices between often divergent communities of practices, As such, the study indicates that there is merit in examining the factors that may obstruct or hinder the creation of value in temporary complex industrial networks. This study, therefore, contributes to an emerging area of industrial scholarship that treats value co-creation in business-to-business networks as far from a foregone conclusion and often a complex proposition (Chowdhury et al., 2016; Mele, 2011), particularly in temporary networks. Thus, our paper strengthens theorization of the dark side of value co-creation with special regard to tension in an inter-organizational context by demonstrating how one individual may have a disproportionate impact on balance.

\section{Managerial Implications, Limitations and Future Research}

Our main findings provide implications for practitioners across several germane areas. To provide the most focused guidance, we follow Jaworski (2011) who advocates four key areas of managerial guidance that can inform our thinking: present actions and present thinking, and 
future actions and future thinking. In terms of present actions, to maintain group unity in networks, practitioners should make use of project planning tools and objects that help manage network activities and goals, and assist task continuity to reduce network tensions. In addition, occasional social activities taking place outside of working hours may also help reduce tensions. Turning to present thinking, the study's results emphasise the importance of brokers in complex project networks, and the role they can play in the creation of informal communication networks, to address any potential network imbalances that may impede value creation.

In terms of future actions, ensuring that 'soft skills' (network management and training for dealing with difficult personality types) are part of industry training alongside 'hard skills' (engineering, design etc.), should prove valuable in this regard. Also, multiple communication channels with clients, unless it is necessary, should be avoided. Finally, in terms of future thinking, the proliferation of complex industrial networks, requires some rethinking in terms of how network cohesion can be managed and tensions (unless they are constructive) are reduced.

Following Social Balance Theory, we place more emphasis on tension as an outcome of the changes in interaction networks. However, in examining relational dynamics tension can be considered both an antecedent and a consequence. The lack of sequential longitudinal data hindered us from examining the processes of tension evolution and spread in the network, and future studies would benefit from being able to compare data from before, during and after an irrevocable event of delivery failure or another major event. 
Future research should address the aftermath (Bengtson et al., 2001) of project relationships (i.e. whether they continue to exist beyond the planned end even if tension was present), and how potential tension-related side-effects, such as blaming (Lam \& Chin, 2005, Balogun, 2003) and passive aggression (Ganesan, 1993) evolve in business networks and impede their effectiveness, particularly in complex industrial networks. Given the dominance of the cocreation of value thesis in marketing scholarship at present, understanding the potential 'dark side' of value co-creation in its many potential hues in a business-to-business context would seem particularly important and timely. 


\section{References}

Abosag, I., Yen, D. A., \& Barnes, B. R. (2016). What is dark about the dark-side of business relationships? Industrial Marketing Management, 55, 5-9.

Abrahamsen, M. H., Henneberg, S. C., \& Naudé, P. (2012). Using actors' perceptions of network roles and positions to understand network dynamics. Industrial Marketing Management, 42(2), 259-269.

Adejumo, G., Duimering, P. R., \& Zhong, Z. (2008). A balance theory approach to group problem solving. Social Networks, 30(1), 83-99.

Andersen, P. H., \& Kumar, R. (2006). Emotions, trust and relationship development in business relationships: A conceptual model for buyer-seller dyads. Industrial Marketing Management, 35(4), 522-535.

Autio, E. (2005). Creative tension: the significance of Ben Oviatt's and Patricia McDougall's article 'toward a theory of international new ventures'. Journal of International Business Studies, 36(1), 9-19.

Balogun, J. (2003). From blaming the middle to harnessing its potential: Creating change intermediaries. British Journal of Management, 14(1), 69-83.

Banner, D. K. (1995). Conflict resolution: a recontextualization. Leadership \& Organization Development Journal, 16(1), 31-34.

Bellotti, E. (2016). Qualitative methods and visualizations in the study of friendship networks. Sociological Research Online, 21(2), 2-21.

Bengtson, A., Havila, V., \& Åberg, S. (2001). Network dependencies and project termination: Why some relationships survive to the end of a project. In Proceedings of the $17^{\text {th }} I M P$ Conference, Oslo, Norway.

Bengtsson, M., \& Kock, S. (2014). Coopetition - Quo vadis? Past accomplishments and future challenges. Industrial Marketing Management, 43(2), 180-188. 
Bengtsson, M., Raza-Ullah, T., \& Vanyushyn, V. (2016). The coopetition paradox and tension: The moderating role of coopetition capability. Industrial Marketing Management, 53, $19-30$.

Borgatti, S. P., \& Everett, M. G. (2013). Analyzing Social Networks. London: Sage.

Borgatti, S. P., \& Everett, M. G. (2006). A graph-theoretic perspective on centrality. Social Networks, 28(4), 466-484.

Borgatti, S. P., \& Everett, M. G. (1992). Notions of position in social network analysis. Sociological Methodology, 22, 1-35.

Borgatti, S. P., Everett, M. G., \& Freeman, L. C. (2002). Ucinet 6 for Windows: Software for social network analysis. Harvard, MA: Analytic Technologies.

Brennecke, J., \& Rank, O. N. (2016). Interplay between formal project membership and informal advice seeking in knowledge-intensive firms: A multilevel approach. Social Networks, 44, 307-318.

Butcher, T. (2013). Longing to belong. Qualitative Research in Organizations and Management: An International Journal, 8(3), 242-257.

Cadotte, E. R., \& Stern, L. W. (1979). A process model of dyadic interorganizational relations in marketing. In J. N. Sheth (Ed.), Research in marketing, Vol. 2 (pp. 127-158). Greenwich, CT: JAI Press.

Campbell, A. J., \& Cooper, R. G. (1999). Do customer partnerships improve new product success rates? Industrial Marketing Management, 28(5), 507-519.

Carson, P. P., Carson, K. D., Knouse, S. B., \& Roe, C. W. (1997). Balance theory applied to service quality: A focus on the organization, provider, and consumer triad. Journal of Business and Psychology, 12(2), 99-120. 
Chowdhury, I. N., Gruber, T., \& Zolkiewski, J., (2016). Every cloud has a silver lining Exploring the dark side of value co-creation in B2B service networks. Industrial Marketing Management, 55, 97-109.

Clarke, A. E. (1991). Social worlds/arenas theory as organizational theory. In Maines, D. R. (Ed.), Social Organization and Social Process. Essays in the Honor of Anselm Strauss. New York: Aldine de Gruyter, 119-158.

Cox, A. (2004). Business relationship alignment: on the commensurability of value capture and mutuality in buyer and supplier exchange. Supply Chain Management: An International Journal, 9(5), 410-420.

Cummings, W. T., Jackson, D. W., \& Ostrom, L. L. (1984). Differences between industrial and consumer product managers. Industrial Marketing Management, 13(3), 171-180.

Das, T. K., \& Teng B. S. (2000). Instabilities of Strategic Alliances: An Internal Tensions Perspective. Organization Science, 11(1), 77-101.

Davis, K. (1977). Human Behavior at Work: Organizational Behavior. (5th ed.). New Delhi: Tata McGraw-Hill.

Doreian, P., \& Krackhardt, D. (2001). Pre-transitive balance mechanisms for signed networks. Journal of Mathematical Sociology, 25(1), 43-67.

Edvardsson, B., Tronvoll, B. \& Gruber, T., (2011). Expanding understanding of service exchange and value co-creation: a social construction approach. Journal of the Academy of Marketing Science, 39(2), 327-339.

Elkjaer, B. (2004) Organizational learning: The "third way". Management Learning, 35(4), 419-434.

Fang, S.-R., Chang, Y.-S., \& Peng, Y.-C. (2011). Dark side of relationships: A tensions-based view. Industrial Marketing Management, 40(5), 774-784. 
Fernandez, A. S., Le Roy, F., \& Gnyawali, D. R. (2014). Sources and management of tension in co-opetition case evidence from telecommunications satellites manufacturing in Europe. Industrial Marketing Management, 43(2), 222-235.

Fink, J. S., Parker, H. M., Brett, M. \& Higgins, J. (2009). Off-field behavior of athletes and team identification: Using social identity theory and balance theory to explain fan reactions. Journal of Sport Management, 23(2), 142-155.

Flint, D. J., Woodruff, R. B., \& Gardial, S. F. (2002). Exploring the phenomenon of customers' desired value change in a business-to-business context. Journal of Marketing, 66(4), 102-117.

Ganesan, S. (1993). Negotiation strategies and the nature of channel relationships. Journal of Marketing Research, 30(2), 183-203.

Gaski, J. F. (1984). The theory of power and conflict in channels of distribution. Journal of Marketing, 48(3), 9-29.

Gilliland, D. I. (2004). Designing channel incentives to overcome reseller rejection. Industrial Marketing Management, 33(2), 87-95.

Granovetter, M. (1985). Economic action and social structure: The problem of embeddedness. American Journal of Sociology, 91(3), 481-510.

Grönroos, C. (2012). Conceptualising value co-creation: A journey to the 1970s and back to the future. Journal of Marketing Management, 28(13-14), 1520-1534.

Håkansson, H., \& Ingemansson, M. (2011). Construction companies and how they acquire. Knowledge through business interaction. The IMP Journal, 5(2), 67-78.

Håkansson, H. \& Ford, D. (2002). How should companies interact in business networks? Journal of Business Research, 55(2), 133-139.

Hanneman, R. A., \& Riddle, M. (2005). Introduction to social network methods. University of California: Riverside, California. Retrieved from http://faculty.ucr.edu/ hanneman/ 
Harrison, D., \& Kjellberg, H. (2010). Segmenting a market in the making: Industrial market segmentation as construction. Industrial Marketing Management, 39(5), 784-792.

Hartman, R. L., \& Johnson, J. D. (1990). Formal and informal group communication structures: An examination of their relationship to role ambiguity. Social Networks, 12(2), 127151.

Heider, F. (1946). Attitudes and cognitive organization. Journal of Psychology, 21, 107-112.

Heidenreich, S., Wittkowski, K., Handrich, M. \& Falk, T., (2015). The dark side of customer co-creation: exploring the consequences of failed co-created services. Journal of the Academy of Marketing Science, 43(3), 279-296.

Hummon, N. P., \& Doreian, P. (2003). Some dynamics of social balance processes: bringing Heider back into balance theory. Social Networks, 25, 17-49.

Järvensivu, T., \& Törnroos, J.-Å. (2010). Case study research with moderate constructionism: Conceptualization and practical illustration. Industrial Marketing Management, 39(1), $100-108$.

Jaworski B. J. (2011). On managerial relevance. Journal of Marketing, 75(4), 211-224.

Johnsen, R. E., \& Lacoste, S. (2016). An exploration of the 'dark side' - Associations of conflict, power and dependence in customer-supplier relationships. Industrial Marketing Management, 59, 76-95.

Johnston, R., \& Pongatichat, P. (2008). Managing the tension between performance measurement and strategy: coping strategies. International Journal of Operations \& Production Management, 28(10), 941-967.

Jones, C., Hesterly, W. S., Fladmoe-Lindquist, K., \& Borgatti, S. P. (1998). Professional service constellations: How strategies and capabilities influence collaborative stability and change. Organization Science, 9(1), 396-410. 
Kotlarsky, J., Oshri, I., \& Willcocks, L. P. (2014). A collection of studies at the country, sector and firm level. London: Springer.

Koza, M. P., \& Lewin, A. Y. (1999). The coevolution of network alliances: A longitudinal analysis of an international professional service network. Organizational Science, 5(10), 638-653.

Lam, P. K., \& Chin, K. S. (2005). Identifying and prioritizing critical success factors for conflict management in collaborative new product development. Industrial Marketing Management, 34(8), 761-772.

Lingo, E. L., \& O'Mahony, S. (2010). Nexus work: Brokerage on creative projects. Administrative Science Quarterly, 55(1), 47-81.

Lusch, R. and Vargo, S. (2014). Service-dominant logic: Premises, perspectives, possibilities. Cambridge, Cambridge University Press.

Makkonen, H., \& Olkkonen, R. (2017). Interactive value formation in interorganizational relationships: Dynamic interchange between value co-creation, no-creation, and codestruction. Marketing Theory, forthcoming

Mele, C. (2011). Conflicts and value co-creation in project networks. Industrial Marketing Management, 40(8), 1377-1385.

Merrilees, B., Rundle-Thiele, S., \& Lye, A. (2011). Marketing capabilities: Antecedents and implications for B2B SME performance. Industrial Marketing Management, 40(3), $368-375$.

Milton, K. (1996). Environmentalism and cultural theory - Exploring the role of anthropology in environmental discourse. London: Routledge.

Mitronen, L., \& Möller, K. (2003). Management of hybrid organisations: a case study in retailing. Industrial Marketing Management, 32(5), 419-429. 
Mohr, J. and Nevin, J. (1990). Communication Strategies in Marketing Channels: A Theoretical Perspective, Journal of Marketing, October, pp. 36-51.

Möller, K., \& Svahn, S. (2004). Crossing East-West boundaries: Knowledge sharing in intercultural business networks. Industrial Marketing Management, 33(3), 219-228.

Monge, P. R., \& Contractor, N. S. (2003). Theories of communication networks, New York: Oxford University Press.

Muhr, T. (2011). ATLAS. ti v6. 2 for Windows. Scientific Software Development, Berlin.

Munksgaard, K. B., \& Medlin, C. J. (2014). Self-and collective-interests: Using formal network activities for developing firms' business. Industrial Marketing Management, 43(4), 613-621.

Newcomb, T. M. (1981). Heiderian balance as a group phenomenon. Journal of Personality and Social Psychology, 40(5): 862-867.

Phillips, J., Liu, B., \& Costello, T. (1998). A balance theory perspective of triadic supply chain relationships. Journal of Marketing Theory and Practice, 6(4), 78-91.

Pressey, A. D., \& Vanharanta, M. (2016). Dark network tensions and illicit forbearance: Exploring paradox and instability in illegal cartels. Industrial Marketing Management, $55,35-49$.

Pryke, S. (2012). Social network analysis in construction. Chichester: Wiley-Blackwell.

Rese, M., \& Roemer, E. (2004). Managing commitments and flexibility by real options. Industrial Marketing Management, 33(6), 501-512.

Schweiger, D. M., \& Denisi, A. S. (1991). Communication with employees following a merger: A longitudinal field experiment. Academy of Management Journal, 34(1), 110-135.

Shibeika, A., \& Harty, C. (2015). Diffusion of digital innovation in construction: a case study of a UK engineering firm. Construction Management and Economics, 33(5-6), 453466. 
Simpson, D. D., \& Dansereau, D. F. (2007). Assessing organizational functioning as a step towards innovation. NIDA Science \& Practice Perspectives, 3, 20-28.

Skarmeas, D., Katsikeas, C. S., Spyropoulou, S., \& Salehi-Sangari, E. (2008). Market and supplier characteristics driving distributor relationship quality in international marketing channels of industrial products. Industrial Marketing Management, 37(1), 23-36.

Smith, M. J., \& Sainfort, P. C. (1989). A balance theory of job design for stress reduction. International Journal of Industrial Ergonomics, 4(1), 67-79.

Spekman, R. E., \& Carraway, R. (2006). Making the transition to collaborative buyer-seller relationships: An emerging framework. Industrial Marketing Management, 35(1), 1019.

Strauss, A., \& Corbin, J. (1998). Basics of Qualitative Research. (2nd ed.). London: Sage.

Sutton-Brady, C., Kamvounias, P., \& Taylor, T. (2015). A model of supplier-retailer power asymmetry in the Australian retail industry. Industrial Marketing Management, 51, 122-130.

Tidström, A. (2014). Managing tensions in coopetition. Industrial Marketing Management, 43(2), 261-271.

Vaaland, T. I., \& Håkansson, H. (2003). Exploring interorganizational conflict in complex projects. Industrial Marketing Management, 32(2), 127-138.

Van Maanen, J. (1978). The Asshole. In Manning, P. K. \& Van Maanen, J. (Eds.), Policing: A View from the Street. Santa Monica, California: Goodyear, 221-238.

Verhallen, T. M., Frambach, R. T., \& Prabhu, J. (1998). Strategy-based segmentation of industrial markets. Industrial Marketing Management, 27(4), 305-313.

Viswanathan, S., \& Wang, J. J. (2004). Inter-dealer trading in financial markets. Journal of Business, 77(4), 987-1040. 
Wasserman, S., \& Faust, K. (1994). Social network analysis: Methods and applications, 8, Cambridge University Press: Cambridge.

Watkins, A., \& Hill, R. P. (2009). A simulation of business-to-business decision making in a relationship marketing context. Industrial Marketing Management, 38(8), 994-1005.

Weerawardena, J., \& Mavondo, F. T. (2011). Capabilities, innovation and competitive advantage. Industrial Marketing Management, 40(8), 1220-1223.

Weinrauch, J. D., \& Anderson, R. (1982). Conflicts between engineering and marketing units. Industrial Marketing Management, 11(4), 291-301.

Woodside, A. G. (2004). Advancing means-end chains by incorporating Heider's balance theory and Fournier's consumer-brand relationship typology. Psychology \& Marketing, 21(4), 279-294.

Woodside, A. G., \& Baxter, R. (2013). Achieving accuracy, generalization-to-contexts, and complexity in theories of business-to-business decision processes. Industrial Marketing Management, 42(3), 382-393.

Woodside, A. G., \& Chebat, J. C. (2001). Updating Heider's balance theory in consumer behavior: A Jewish couple buys a German car and additional buying-consuming transformation stories. Psychology \& Marketing, 18(5), 475-495.

Woodside, A. G., \& Wilson, E. J. (2003). Case study research methods for theory building. Journal of Business \& Industrial Marketing, 18(6/7), 493-508.

Wuyts, S., \& Geyskens, I. (2005). The formation of buyer-supplier relationships: Detailed contract drafting and close partner selection. Journal of Marketing, 69(4), 103-117.

Yin, R. K. (1994). Case study research: Design and methods. London: Sage. 
Figure 1: Successful Project - Formal communications

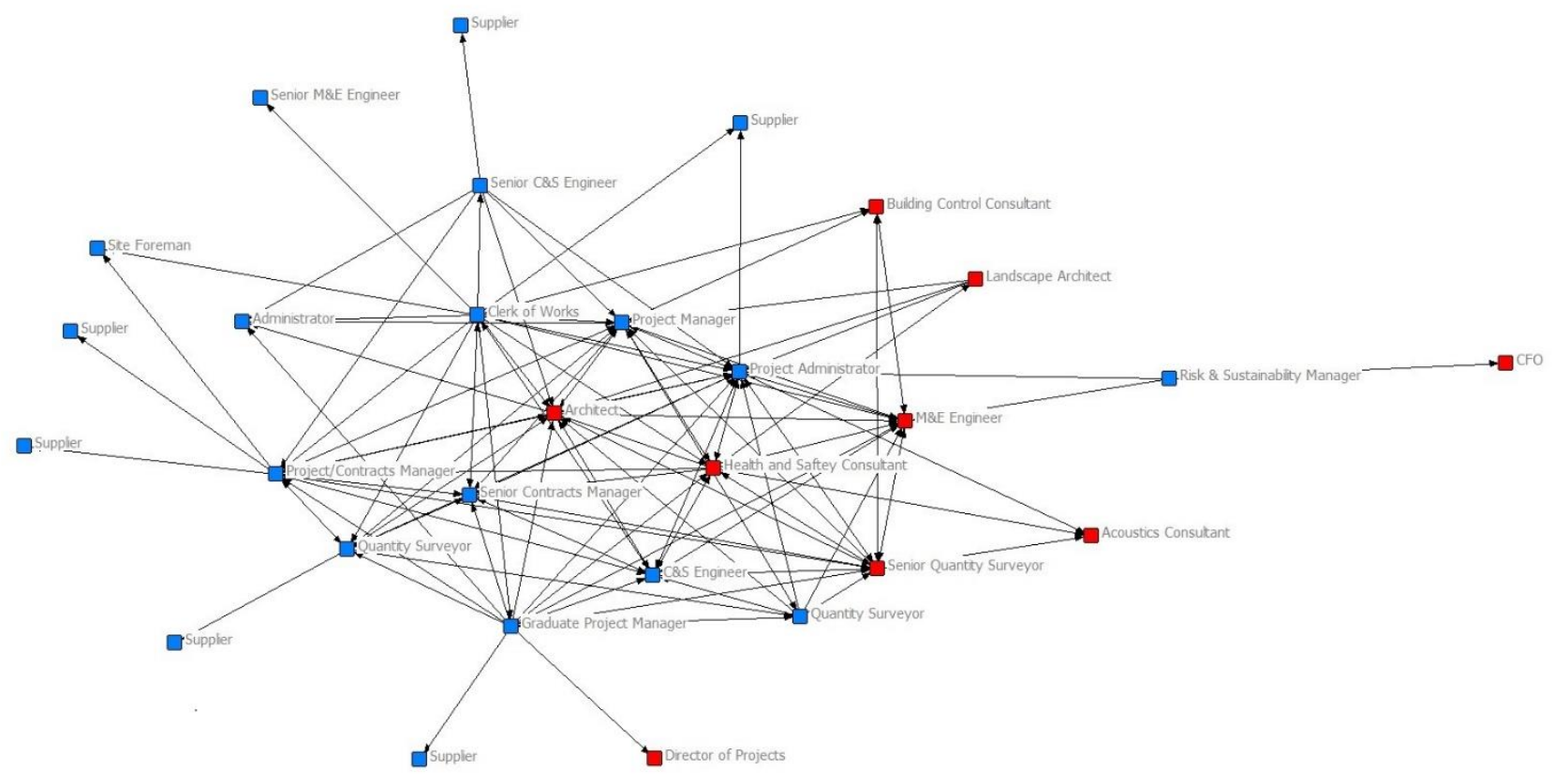


Figure 2: Successful Project - Informal communications

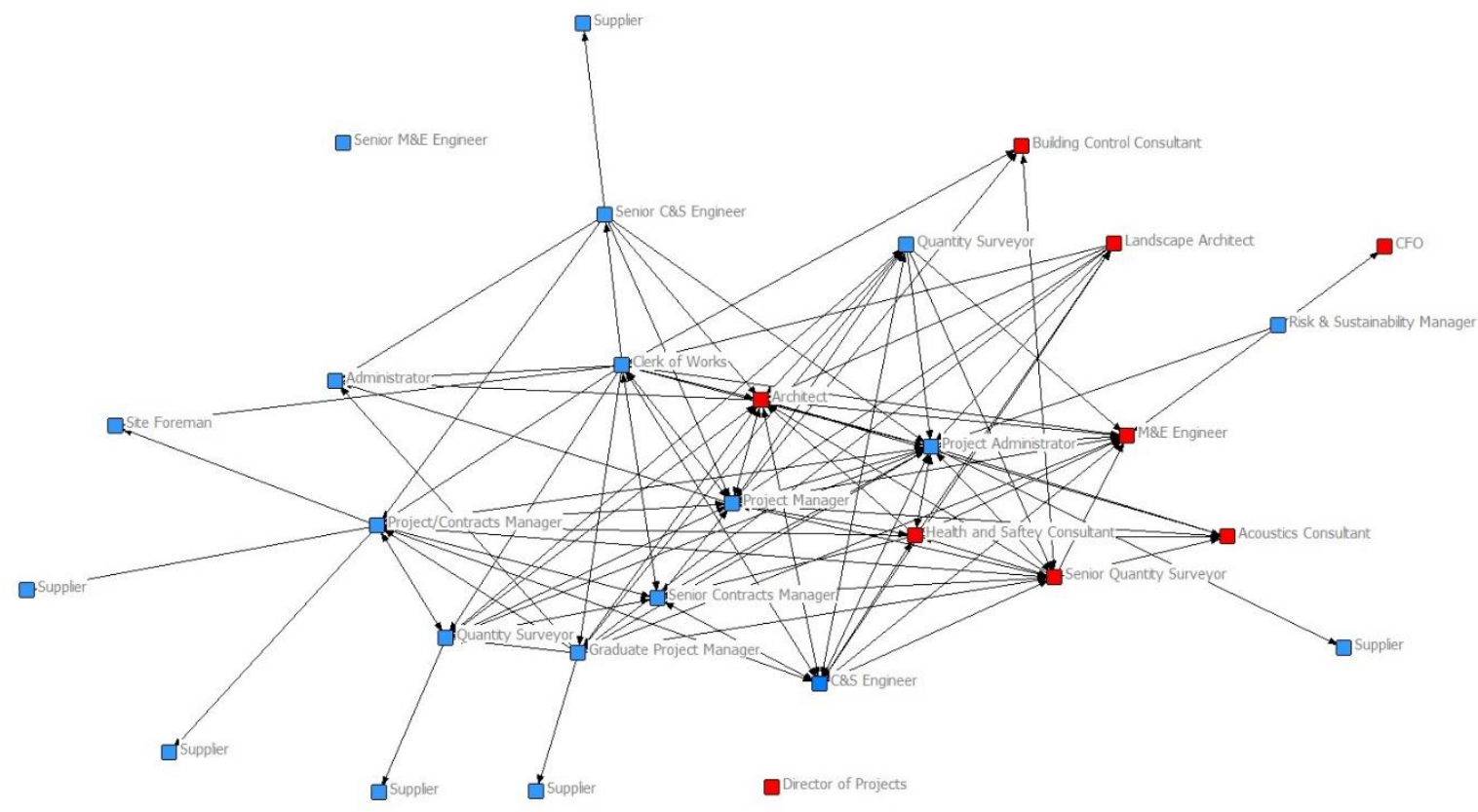


Figure 3: Dysfunctional Project - Formal communications

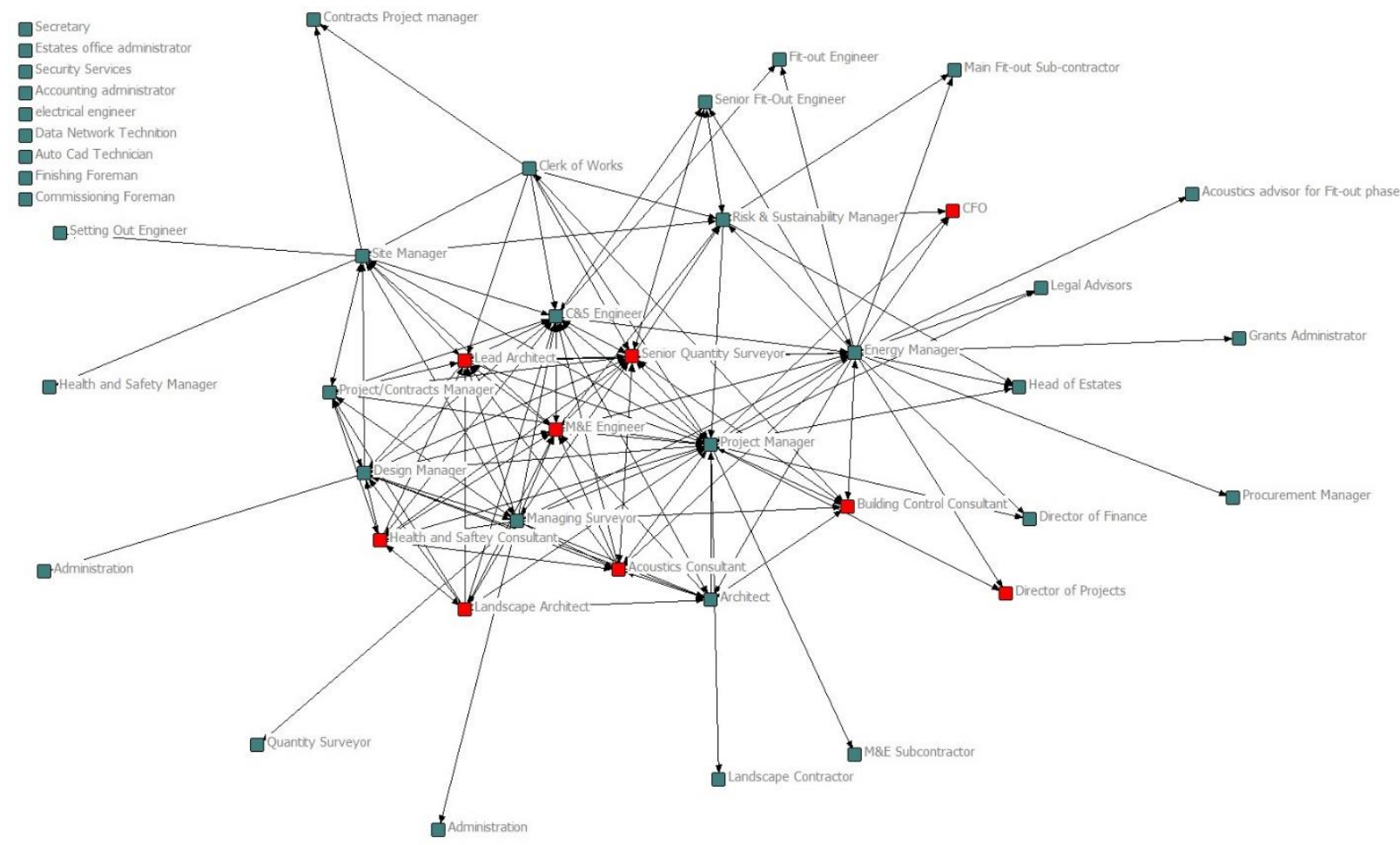


Figure 4: Dysfunctional Project - Informal communications

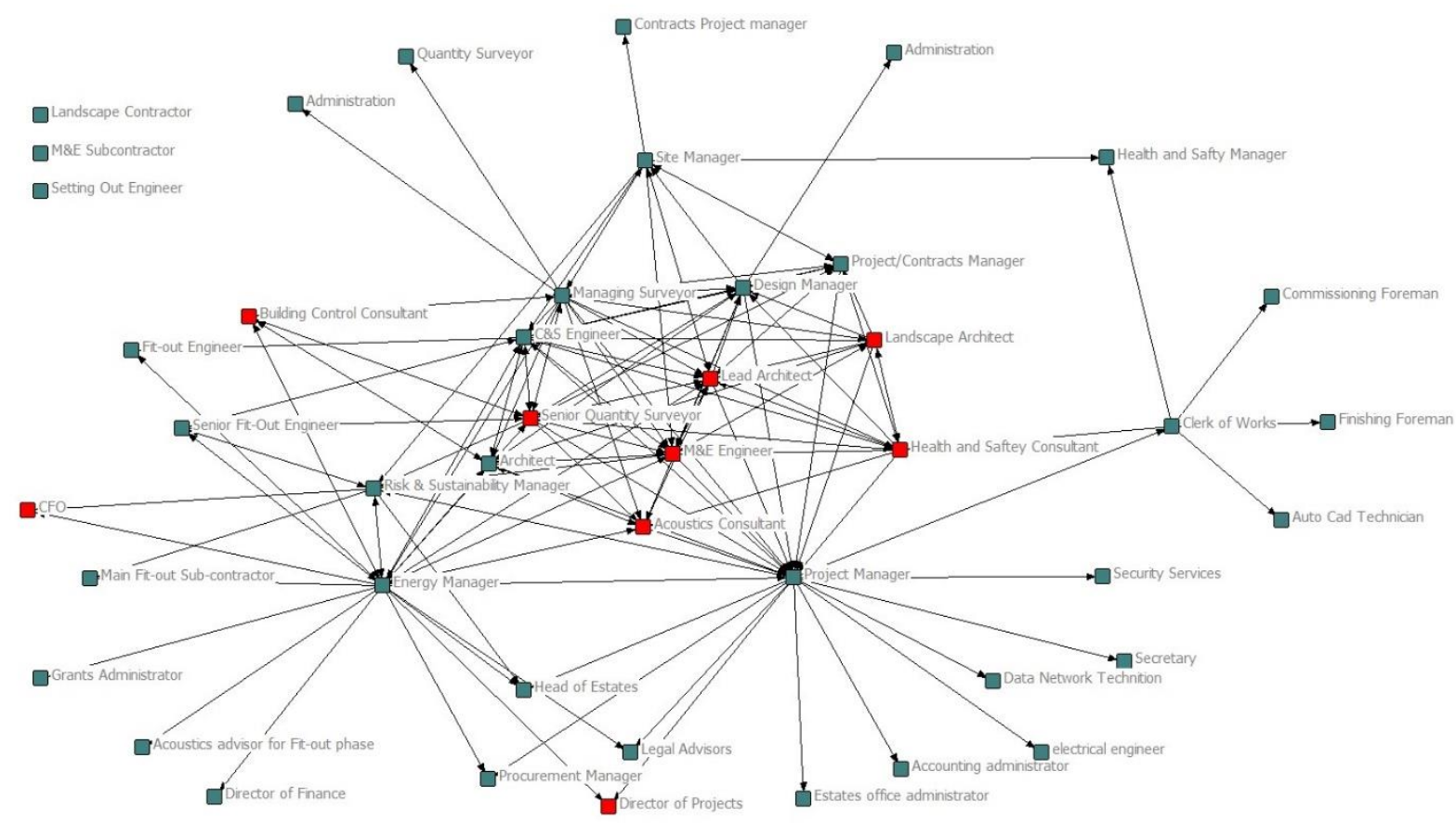


Figure 5: Rotated informal communications network of the Dysfunctional Project

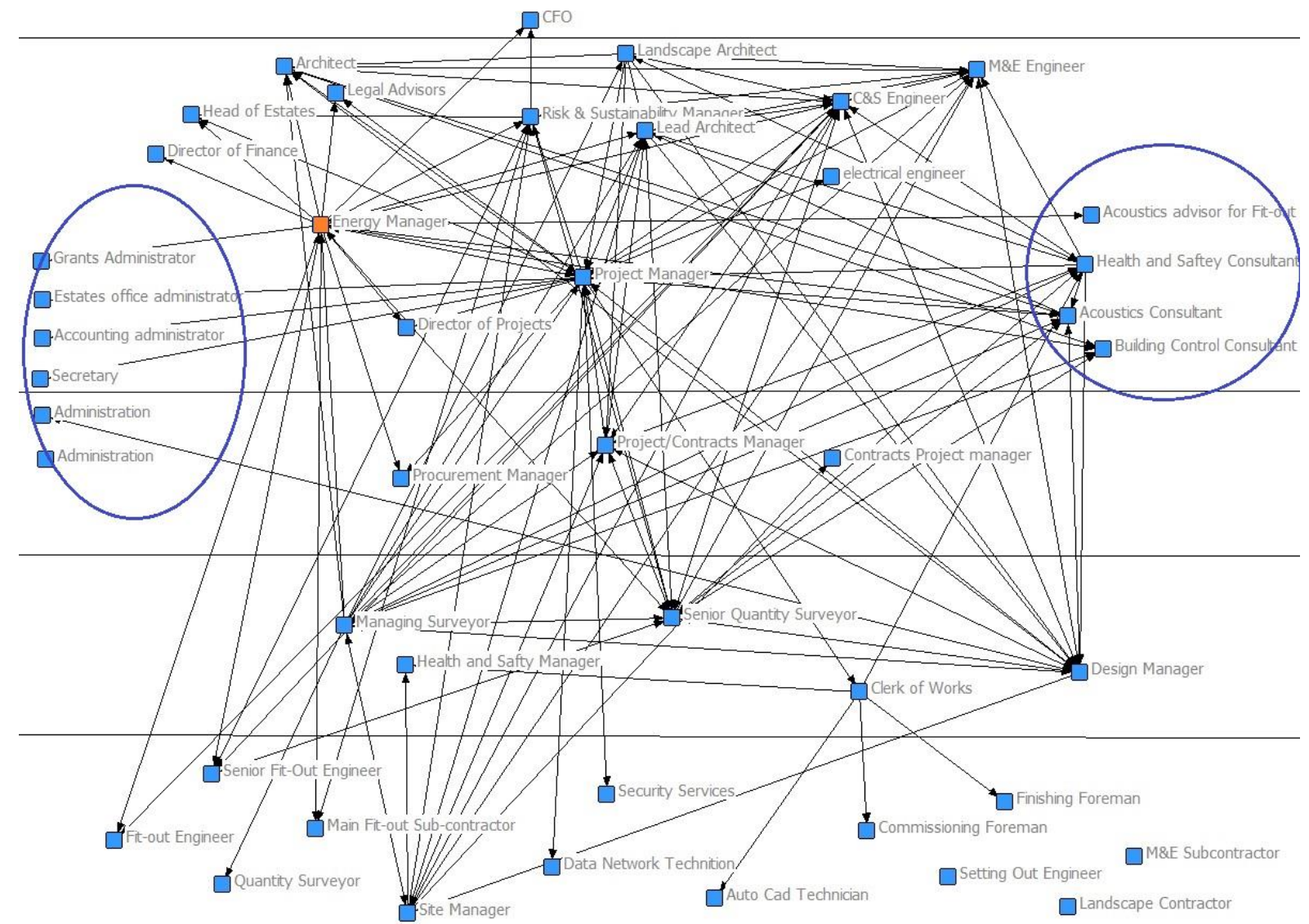


Figure 6 Tension network: the fit-out team and the design team

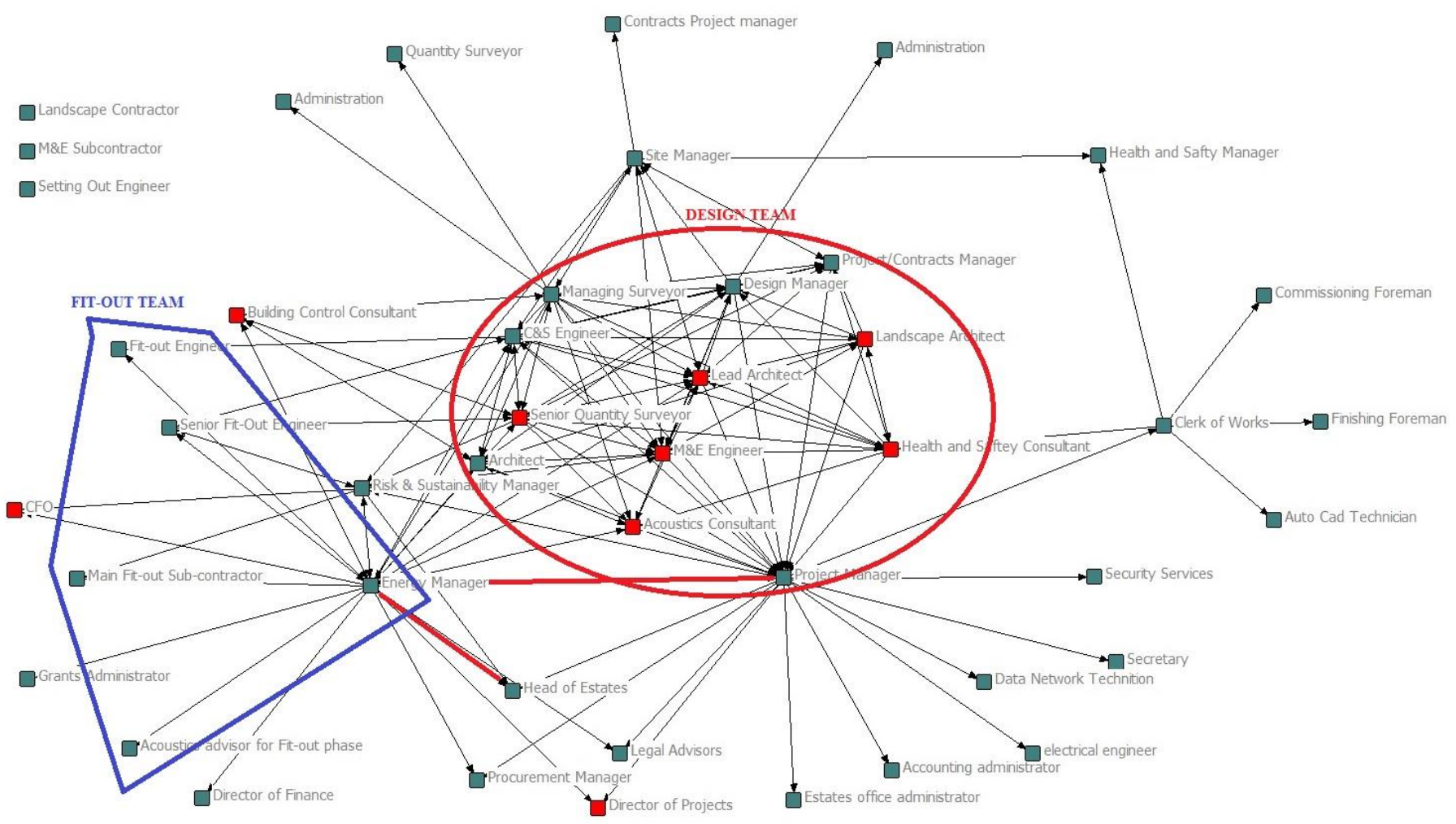

